\title{
A TÁVOLLÉTI OKTATÁS TANULSÁGAI 2020-BAN: FELSŐOKTATÁS (EKE), KÖZOKTATÁS, ISKOLAI KÖNYVTÁRAK
}

\author{
ANTAL PÉTER - CZEGLÉDI LÁSZLÓ \\ Eszterházy Károly Egyetem \\ Digitális Technológia Intézet
}

A távolléti oktatás kifejezés nem azonos a távoktatás vagy az e-learning fogalmakkal. A távolléti oktatás egy pillanatnyi állapotra utal, amelyet jelenleg a pandémia révén kialakult helyzet keltett életre. Ugyanakkor - mivel nincs más - kénytelenek vagyunk az eddig használt módszereket alkalmazni a jelenlegi helyzetre.

Az Eszterházy Károly Egyetemen 2010 óta használjuk a MOODLE távoktatási keretrendszert több-kevesebb sikerrel. Évek óta működik egy kutatócsoport, amelynek feladata az interaktív, online kurzusokhoz kapcsolódóan a tanulási eredmények monitorozását lehetővé tévő eszközök, alkalmazások kísérleti beépítése, illetve újak kifejlesztése. Ennek egyik része az a vizsgálat, amely a felhasználók elégedettségét (tanár, diák) és kompetenciáját méri. A COVID-19 okozta hirtelen változások nyilvánvalóvá tették, hogy mind a diákok, mind a tanárok, egyetemi oktatók jó része nem készült fel a digitális oktatás kihívásaira sem módszertani, sem technikai szempontból. Kutatásaink kiterjedtek az iskolai könyvtárak helyzetének és szerepének vizsgálatára is, hiszen az iskolai könyvtárak képviselik egy iskola minőségi mutatóinak jelentős százalékát.

A könyvtár-pedagógia területe jelenleg még küzd a digitális világ kihívásaival. A megújuló tantervi változások lehetőségei még nem láttatják, hogy milyen irányban kell folytatni a munkát ezen a területen, milyen iskolai stratégiával, könyvtári elképzelésekkel lehet a megjelenő problémákat orvosolni a mindennapi oktatásban, a várható új tantervi elvárásoknak megfelelően. Tegyük hozzá természetesen azt a tényt, hogy a mindennapi oktatás módszertana, technológiája természetesen nem vagy nagyon nehezen követi ezeket az elvárásokat. Ráadásul a tapasztalatok azt mutatják, hogy az itt feltárt tények kihatással vannak a felsőoktatásban történő részvétel minőségére is.

Tanulmányunkban ezek alapján vizsgáljuk a pandémia okozta anomáliák kérdéseit a felsőoktatásban (EKE), a közoktatásban és az iskolai könyvtárakban. (Az Eszterházy Károly Egyetem Digitális Technológia Intézetének kutatásai a pandémia eddigi időszakának oktatási tapasztalatairól, különös tekintettel a technika integrációra) 


\section{Bevezetés}

Valahol olvastuk: nem a rossz híreket kell elfogadni, hanem a jó megoldásokat kidolgozni. Ennek szellemében történnek egyetemünk, tanszékünk kutatásai, tanulmányai.

A kutatások eredménye egyértelmű: vissza kell térnünk az oktatástervezés gyökereihez. Újra kell gondolni az annak idején megalkotott programozott oktatás alapjait. (Skinner, 1954; Fuchs, 1971) Ha nem nyúlunk vissza az alapokhoz, akkor semmi esélyünk sincs arra, hogy újra megértsük azt a folyamatot, amely eljuttatott bennünket addig, hogy esélyünk legyen megértetni az emberekkel (elsősorban a diákokkal) azt, hogy a változás a küszöbön áll, rajtunk múlik.

Min múlik? Azokon a visszajelzéseken, ameyeket kapunk, és azon, hogy ezek közül mit vagyunk hajlandók elfogadni. Ma, sajnos, többet kell elfogadni, mint szeretnénk. Ezért még fontosabb, hogy ezt tegyük. Ehhez próbál segíteni az az átfogó vizsgálat, amely az oktatási területek egy részének problémáit próbálja bemutatni, elemezni a 2020. év tükrében. Számot vetve azzal, hogy ez az oktatás területén egy nagyon szerteágazó kérdés.

Az Eszterházy Károly Egyetemen a programozott oktatás nem újkeletü történet, hiszen a programozott oktatás Magyarországon az 1960-as években indult meg, minden esetben figyelemmel kísérve a nemzetközi trendeket, történéseket. Ennek eredményei vezettek egyetemünkön hosszú évek tapasztalatain keresztül az internetes távoktatás bevezetéséig (kb. a 2000. év elejéig). Fontos kérdés ezen belül, hogy mit tanultunk az előző kutatásokból, kutatási elképzelésekből. Néha úgy tűnik, hogy alig valamit, de szerencsére legtöbbször az eredmény pozitív.

A digitális átállás (Racsko, 2017) fontos, népszerű és szerteágazóan feldolgozott fogalom, ráadásul nemcsak fogalom, hanem gyakorlat is. A különböző kutatások eredményei azonban rávilágítanak legalább néhány fontos kérdésre vagy továbblépési pontra:

- Mikor kezdődött ez a folyamat?

- Miért vált szükségessé ez a folyamat?

- Milyen előnyökkel, illetve hátrányokkal jár ennek a folyamatnak a lezajlása?

- Létrejött-e a digitális átállás, és milyen mélységben?

- Melyek azok a pontok, ahol nem vagy nehezen jön létre a digitális átállás?

- Mindenki akarja a digitális átállást? (természetes lehetőség, tehetetlenség, „kényszerítés”)

A digitális átállás fontos és elkerülhetetlen folyamata a jelennek és a jövőnek, de nem ennek a tanulmánynak a feladata megfelelni a kérdésekre, csak segítséget próbálunk nyújtani a megítéléshez. 
Az oktatás sok területén rengeteg tapasztalt van az IKT alkalmazásával és hasznosságával kapcsolatban, amit több kutatási eredmény is igazol. A számítógépes alkalmazások előnyei között a szerzők legtöbbször külön kiemelik az eszközök motiváló hatását. A gyakorlati tapasztalatokat megerősítve több kutatás is igazolja, hogy az IKT-eszközök használatának már önmagában is jelentős motiváló ereje lehet. (Antal, 2020)

Sorra kell venni: mit tudunk, mit akarunk és mik a lehetőségek. Elcsépelten hangzik. Pedig pont ezeket nem vettük figyelembe az elmúlt év elején, amikor még azt hittük, hogy mindenre van megoldás.

Sajnos kiderült, a Covid-19 teremtette helyzet teljesen ismeretlen terület az oktatás szervezése, lebonyolítása, a technikai lehetőségek és megvalósítások szempontjából. Így olyan kutatások elvégzésére is alkalom nyílt, amelyeket csak egy adott helyzetben tudunk elvégezni, vagyis a járványhelyzet egy jó pillanatképet ad a magyar köz- és felsőoktatás jelenlegi helyzetéről a digitális átállás és a digitális kompetenciák színvonalának kapcsán.

Az Eszterházy Károly Egyetem Humáninformatika Tanszéke legalább három-négy irányban folytat ezen a területen kutatásokat már évek óta: a digitális átállás, a digitális pedagógia, a digitális könyvtár-pedagógia, a digitális-többrétegű műveltség, (Lengyelné, Szűts, Racsko, 2020) stb. elemzése és fejlesztése területén.

Ezeken belül jelenleg három területen elvégzett kutatási eredményeink egy részét szeretnénk közzétenni a következő témákban: ingyenes szoftverek, iskolai és egyéb szolgáltatások, iskolai könyvtárak tanári használóinak véleménye a jelenlegi helyzetről.

\section{Felsőoktatás}

Mit jelent a felsőoktatásban az informatizálás?

Innen indult, de mára kiderült, hogy mégsem érte el azokat az eredményeket, amelyek szükségességét már - bátran kijelenthetjük - az 1970-es évektől megfogalmazták a terület kutatói. Sokféle kutatás született ebben a témában, amelyek kezdetben azt vizsgálták, hogy a meglévő „szoftverhez” miként lehetne megfelelő hardvert találni. Ma már komplexebb és kétirányú a történet, hiszen a tartalom és a hardver szinte minden területen együtt áll, a legtöbb esetben mégsem tudjuk hatékonyan használni a kettőt együtt!

Az okokat vizsgálva kiderül, hogy nem újkeletű a probléma.

P. A. Ertmer szerint a hatékony technológiai integráció hiánya az oktatásban néhány alapvető okra vezethető vissza. Az első okcsoportba sorolhatjuk azokat a külső tényezőket, amelyek az oktatóktól függetlenek. Ide tartozik a számítógépekhez és a szoftverekhez való hozzáférés hiánya (az utóbbi időben ez egyre javuló tendenciát mutat), kevés idő jut a korszerü technikával támogatott oktatás megtervezésére, ezen kívül pedig sok esetben nem megfelelő 
a műszaki és adminisztrációs háttértámogatás. A második okcsoportban találjuk a belső tényezőket, mint az oktatásba és a pedagógiába vetett hit, bizalom a számítógépek vagy a technológia iránt, a bevált osztálytermi gyakorlatok, valamint a változásokkal, az újjal szemben érzett vonakodás. (Ertmer, 1999) Ezzel együtt nyugodtan kijelenthetjük, hogy a technológiai oldal megoldásai nem egyedül képezik a megoldást.

Egy korábbi tanulmányban összefoglalásra került, hogy melyek azok a tényezők, amelyeket figyelembe kell venni a téma vizsgálatához. Ennek alapján megállapíthatjuk, hogy „egy ilyen irányú technikai integráció, vagy egy intézmény informatizálására való törekvés nem csupán anyagi kérdés. A bevezetés előtt azonban fel kell mérni az országos és helyi környezet lehetőségeit (számítógéppel rendelkezők száma, internethasználat stb.), a különböző folyamatok - társadalmi és technológiai egyaránt - irányát és jellemzőit, valamint a virtuális tér infrastruktúrájának kialakítására rendelkezésre álló szellemi, technikai és anyagi erőforrásokat. Emellett meg kell vizsgálni az eszközhasználat módszertanának elméleti és gyakorlati kérdéseit nem csak a jó gyakorlatok tekintetében, hanem a helyi viszonyokra való alkalmazhatóság oldaláról is.” (Czeglédi, 2009)

A jelenlegi helyzetben erre nem volt lehetőség, de a kutatások tapasztalatai azt is mutatják, hogy messze nem voltunk felkészülve arra a helyzetre ezen a területen, amelyet a pandémia okozott. Ráadásul az említett tényezők nemcsak a felsőoktatást érintik, hanem amint látni fogjuk, a közoktatást és a közoktatást támogató - elsősorban kulturális irányultságú - intézményeket is.

A felsőoktatásban évek óta alkalmazunk különféle e-learning keretrendszereket az oktatás korszerüsítésének érdekében. Egyre nő a hozzáférhető kurzusok száma is, amelyek alternatívái lehetnek a kontakt képzéseknek. Az Eszterházy Károly Egyetemen 2010 óta használjuk a MOODLE távoktatási keretrendszert, több-kevesebb sikerrel. Ezzel párhuzamosan létrejött egy kutatócsoport, amelynek feladata az interaktív, online kurzusokhoz kapcsolódóan a tanulási eredmények monitorozását lehetővé tévő eszközök, alkalmazások kísérleti beépítése, illetve újak kifejlesztése a MOODLE-ban. Ennek egyik része az a vizsgálat, amely a diák és oktató felhasználók elégedettségét és kompetenciáját méri. Eddig sok oktatónk nem élt ennek a lehetőségével, de szomorú aktualitásként a koronavírus járvány azokat a kollégákat és hallgatókat is belekényszerítette a MOODLE használatába, akik eddig kevésbé ismerték. A tapasztalatok azt mutatják, hogy a koronavírus-járvány kezdetén a diákok és az egyetemi oktatók jó része nem volt felkészülve a digitális oktatás kihívásaira, sem módszertani, sem technikai szempontból. 


\section{Mit adott nekünk a Covid-19?}

Az egyetemi e-learning-rendszer tesztelésére, hiányosságainak feltárására és használatának elemzésére sajnálatosan jó lehetőséget nyújtott a koronavírus-járvány teremtette helyzet. 2020 március elejétől a nappali és levelezős képzés is távoktatási formában valósult meg. A rendelkezésre álló egy hét alatt kellett megteremteni azon oktató kollégák és hallgatók részére a feltételeket, akik eddig nem használták a MOODLEt.

A Digitális Technológia Intézet berkein belül elkészült egy online videótréning hallgatók és oktatók számára, amely a MOODLE rendszer alapvető használatát és kezelését mutatta be, különös tekintettel a belépés módjára, a kurzusok létrehozására, a tartalom feltöltésére, megosztására, a számonkérés módjaira, a csoportok hozzárendelésére.

További nehézségeket okozott, hogy a MOODLE nem tartalmaz online videókonferencia-rendszert, így egyéb alternatívákat kellett kínálni az oktatóknak. Többségükben a Zoom vagy a Microsoft Teams felületét használták.

\section{A kutatás lebonyolítása}

A projekt azért indult, hogy a MOODLE használatát egyszerűbbé tegye a hallgatói és oktatói igényeknek megfelelően. Eddig egy szűk keresztmetszetben vizsgálhattuk a felhasználók igényeit, hiszen nem használta minden oktató és diák.

A projekt a következő kutatási területeket tartalmazta:

1. A projekt során lezajlott a MOODLE (LMS) rendszer kompetenciaalapú képzési lehetöségeihez kapcsolódó szolgáltatások elemzése.

2. Releváns, hazai és nemzetközi megvalósitások kutatása, jó gyakorlatok megismerése, különös tekintettel az EKE alkalmazott tanulásmenedzsment rendszerében megvalósitható implementációkra.

3. Hallgatói és oktatói vélemények, tapasztalatok, javaslatok gyüjtése a használattal, eredményességgel kapcsolatban.

4. Az adatok elemzése és fejlesztési terv készitése a legproblémásabb funkciók módositására.

5. Programozás, tesztelés és az eredmények végleges beépitése a MOODLE alkalmazásba.

Jelen tanulmányban a hallgatói és oktatói vélemények, tapasztalatok, javaslatok gyüjtésének eredményeit részletezzük a használattal és eredményességgel kapcsolatban.

A hallgatók és oktatók részére összeállítottunk egy 20-20 kérdésből álló Unipoll kérdőívet, és miniinterjúkat is készítettünk. Ezek célja, hogy a kérdésekre adott válaszok 
összehasonlíthatók legyenek, és a megvalósítás szempontjából hasznos információkkal szolgáljanak, vagyis az eredmények rávilágítsanak a MOODLE-ben a fejlesztendő területekre.

A kérdőíveket a Neptun rendszeren keresztül publikáltuk, 82 oktató és 681 hallgató töltötte ki azokat.

\section{Eredmények}

A kérdőíves vizsgálat eredményei közül a továbbiakban a használhatóságra, a MOODLE jelenleg is elérhető szolgáltatásaira és ezek hasznosságára vonatkozó válaszokat ismertetjük.

A kérdőíveket a legtöbben a pedagógiai és az informatikai karok hallgatói és oktatói töltötték ki. Ez nem véletlen, hiszen ezen a két karon volt eddig is a leggyakoribb a MOODLE használata. A hallgatók részéről a kitöltők 61\%-a nappali tagozatos hallgató volt. (1. ábra)

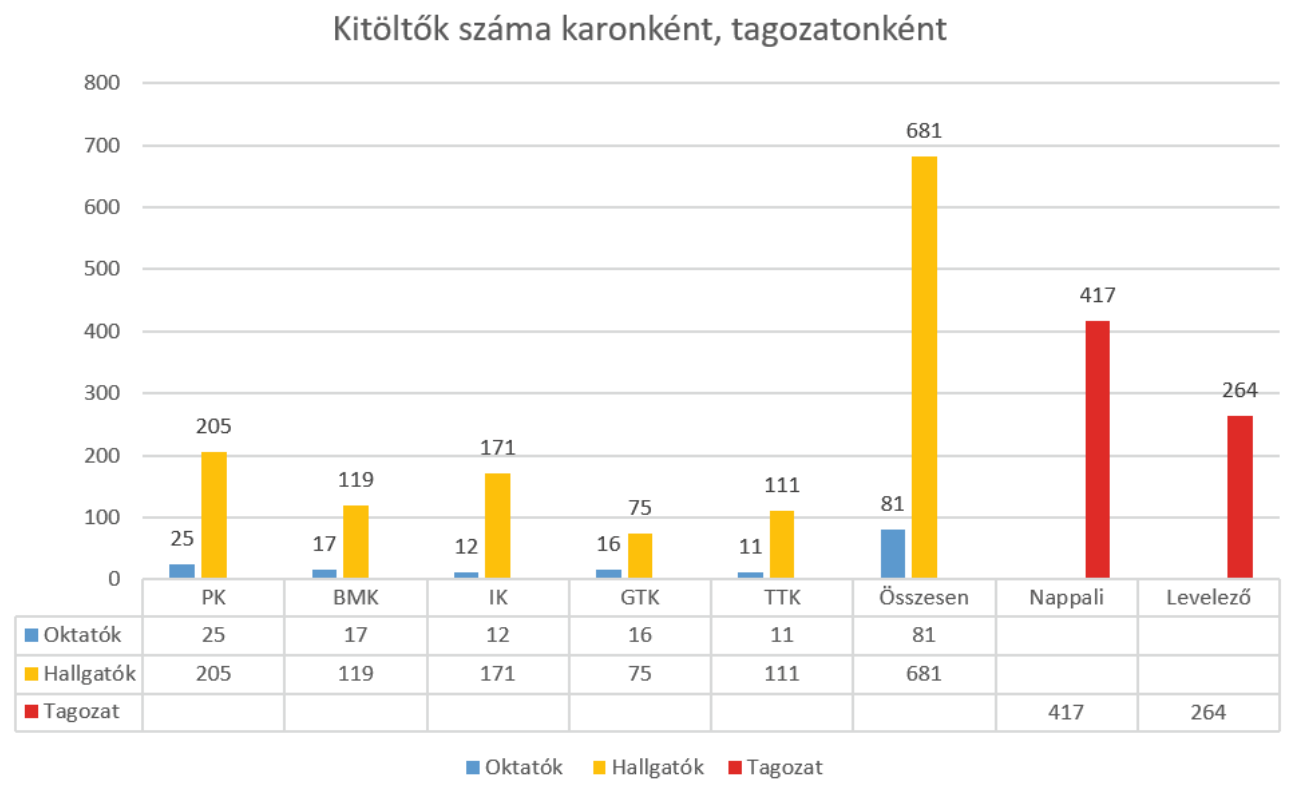

1. ábra. A kitöltök megoszlása karonként és tagozatonként 
Az első kérdéscsoport a felület használhatóságát és arculatát vizsgálta mindkét megkérdezett csoportban. Az eredmények alapján elmondható, hogy a felhasználók közel 80\%-a elégedett a kezelhetőséggel, így ebben a kérdésben nem volt változtatnivaló a MOODLEban. (2. ábra)

\section{Mennyire volt elégedett volt a felület arculatával?}

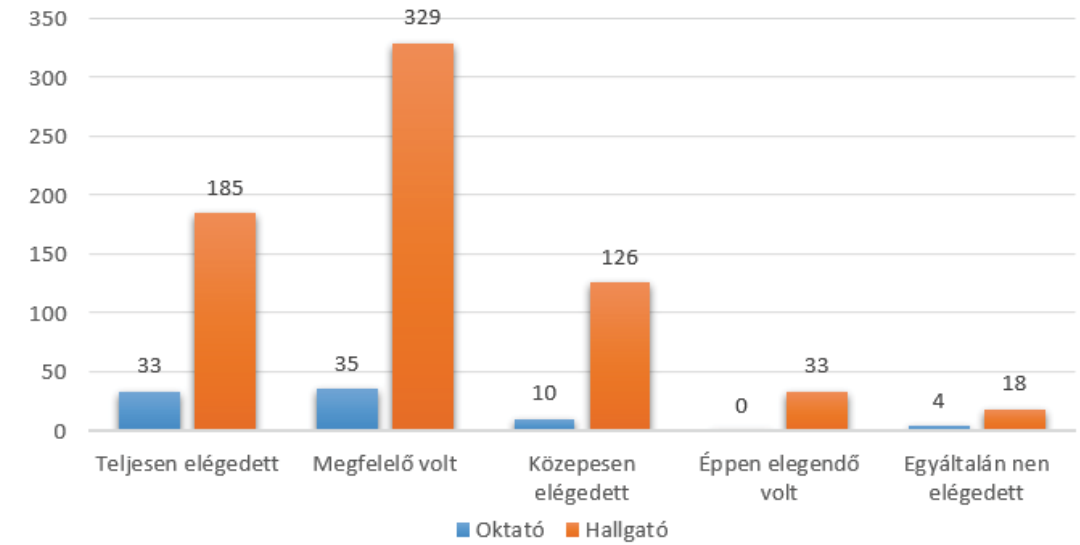

Mennyire tartotta áttekinthetőnek a felületet?

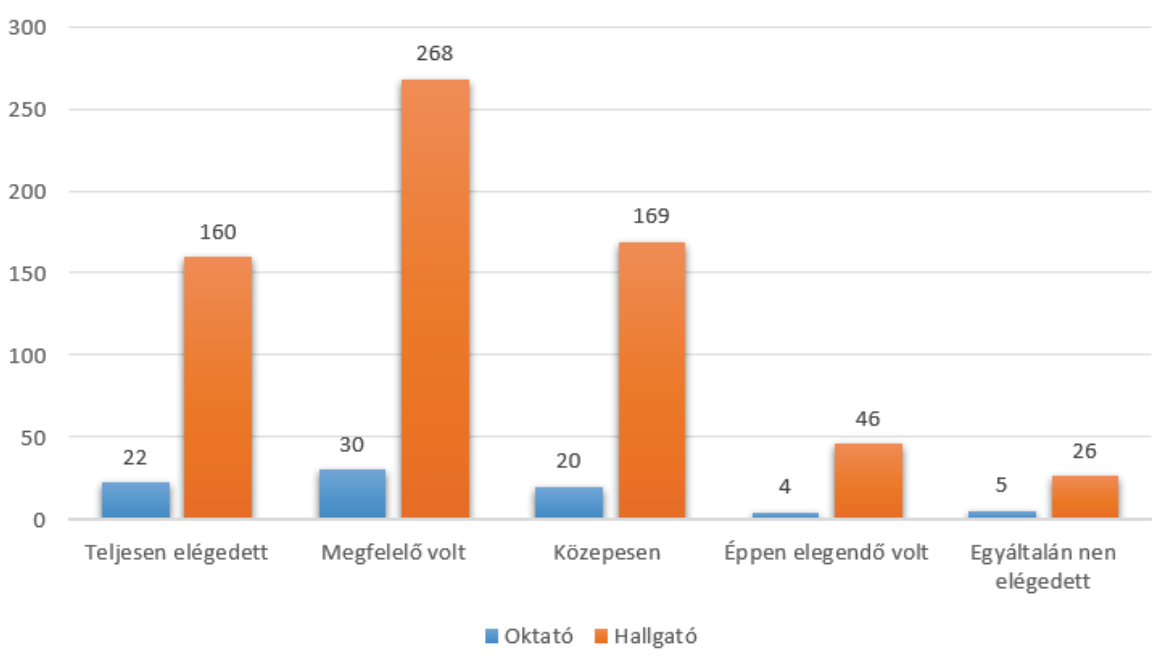

2. ábra. A webdesign minöségére adott válaszok 
A következő kérdéscsoportban arra kérdeztünk rá, hogy a MOODLE által megosztható médiatípusokból melyeket preferálták és használták a tanárok, illetve mely tartalom és feladatmegosztással kapcsolatos szolgáltatásokat vettek igénybe és milyen formában. A hallgatók esetén pedig arra kerestük a választ, hogy mely szolgáltatásokkal találkoztak a használat során. Az eredményekből látható, hogy az oktatók 90\%-a valamilyen szöveges formában osztotta meg a tananyagokat, ami az e-learning szempontjából nem a legelegánsabb megoldás. Pozitívumnak tekinthető, hogy a lehetséges opciók közül mindegyiket használták, talán a tanári videók (órafelvételek videói) alkalmazása tűnik kevésnek. Ugyanakkor a kollégák 44\%-a már interaktív tananyagot is alkalmazott bizonyos esetekben. (3. ábra)

\section{Milyen formában osztotta meg a tananyagokat?}

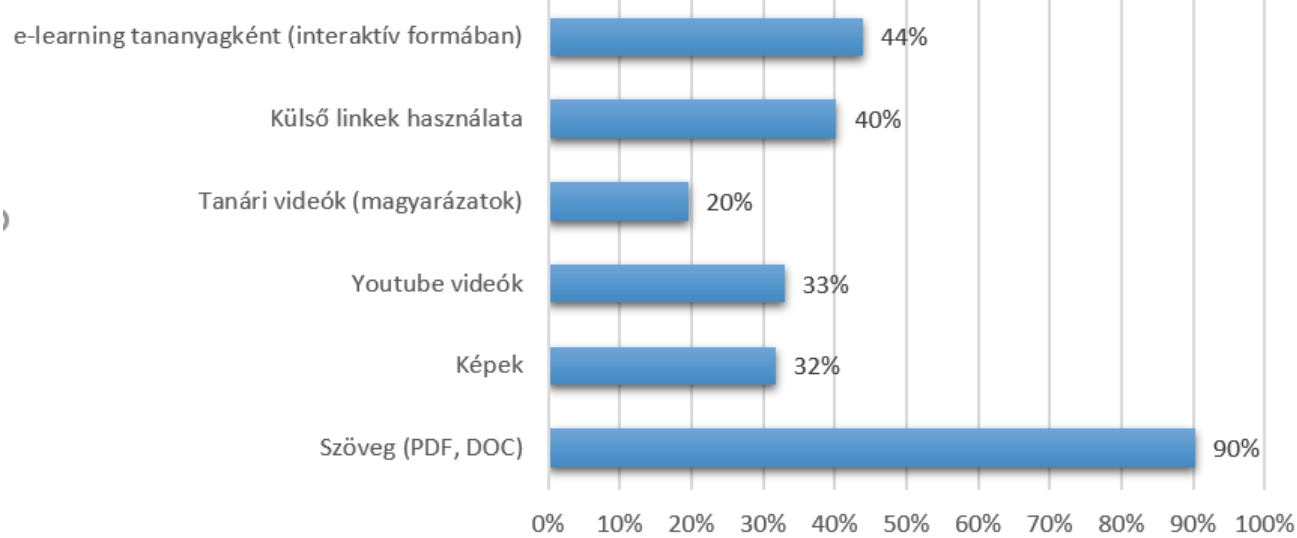

3. ábra. Az alkalmazható tananyagmegosztási lehetöségek típusai és arányai

Az elérhető szolgáltatásokkal kapcsolatban szembetűnő, hogy az elektronikusan kiadott tananyagok aránya az oktatók szerint nagyon magas, de ebben benne vannak az egyszerü elektronikus szövegként kiadott tananyagok is. A leggyakrabban használt szolgáltatásoknak a feladatok beküldése és a külső források linkjeinek megadása bizonyult, mindkettővel a felhasználók több mint 50\%-a találkozott.

A tanári videók tekintetében látható nagyobb különbség a hallgatói és oktatói megítélésben, ez valószínűleg abból fakad, hogy a diákok nemcsak az órafelvételeket tekintették tanári videónak, hanem a más forrásból származókat is.

Magas arányt ért el a vizsgáztatási lehetőségek kihasználása is, az oktatók 51\%-a élt a MOODLE vizsgáztatási lehetőségeivel.

A kommunikációs szolgáltatások (chat, fórum) tekintetében közel 50\%-os eredmény született mindkét felhasználói oldalról. (4. ábra) 
Mely szolgáltatásokat vette igénybe, illetve melyekkel találkozott a MOODLE rendszer használata során?

Külsố linkek (weboldalak, videók, for rások beépítése a tananyagba)

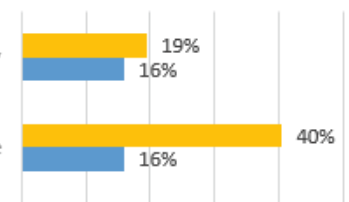

Tanári videók készitése
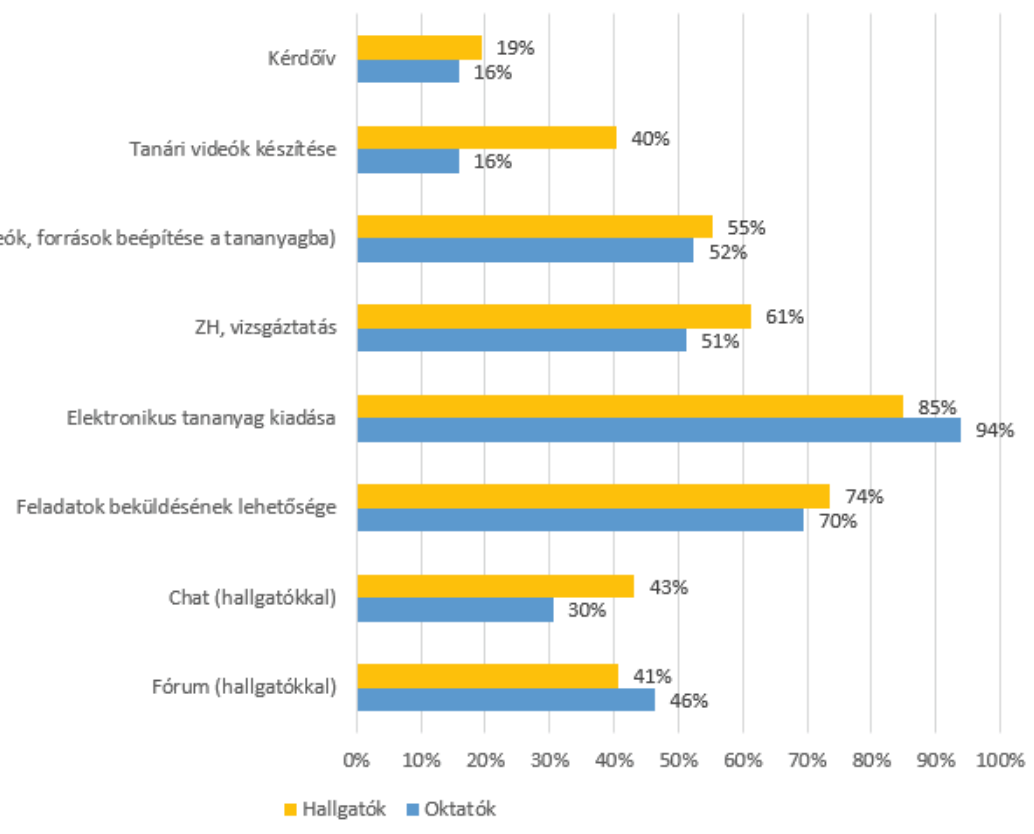

4. ábra. A tartalommegosztó és kommunikációs szolgáltatások használatának eredményei 
A MOODLE vizsgáztatási lehetőségeivel kapcsolatban sok probléma merült fel, amelyet jól reprezentál a követkető ábra. Nehézkes a tesztek és kérdések exportja-importja egyaránt, nem minden kérdéstípust támogat, szerkesztőfelülete nehezen áttekinthető. Nehezen használható az értékelőfelület, a beküldendő feladatok ellenőrzése, visszajelzési rendszere és adminisztrációja is. Az oktatók közel fele volt valamelyik felsorolt okból elégedetlen a használattal, illetve nem volt tisztában a működésével. (5. ábra)

\section{Mennyire volt elégedett a tesztek és a beküldött feladatok kiértékelési lehetőségeivel?}

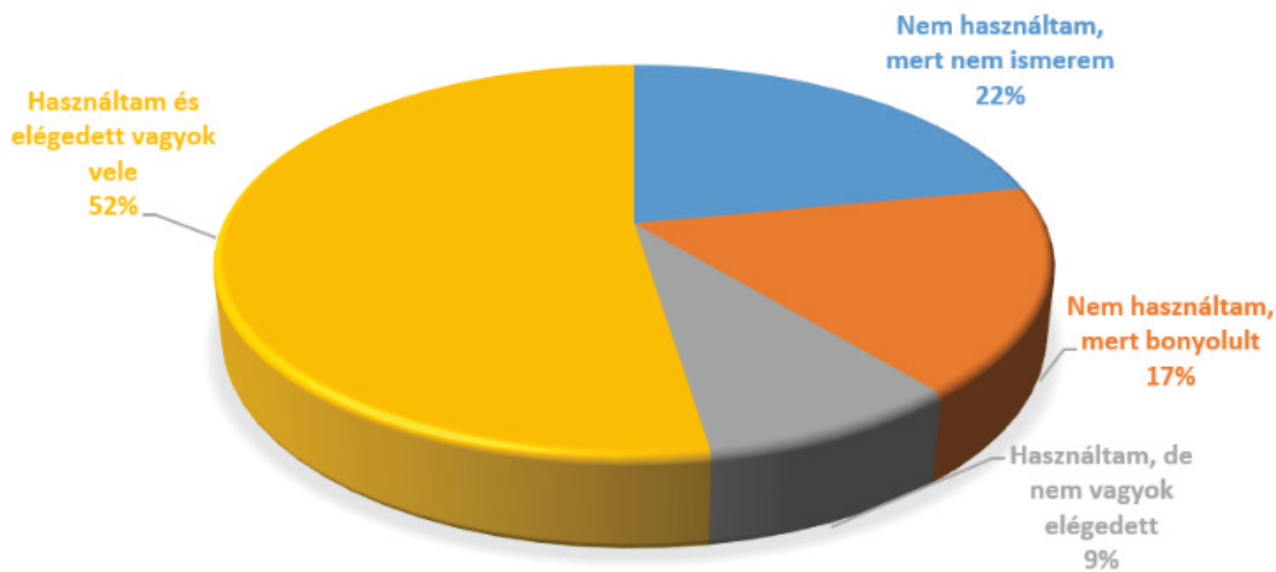

5. ábra. A vizsgáztatási rendszer használatának eredményei

A következő kérdésben arra voltunk kíváncsiak, hogy mi okozta a legnagyobb gondot a rendszer használata során. A legnagyobb mértékben a tapasztalatlanságot jelölték meg a bizonytalanság okaként, ez a hallgatók és oktatók esetében is meghaladta az 50\%-ot. Láthatóan az oktatók számára jelentett nagyobb kihívást a felület bonyolult használata elsősorban a navigáció és a strukturálatlan felület miatt. A hallgatók részéről a belépés és a felhasználói tájékozatlanság jelentett gondot, amit alátámaszt az is, hogy 22\% a felkészítést tartotta elégtelennek. Ami már nagyobb problémát jelent, az a felületen való eligazodás, a kiemelések hiánya, illetve a kurzusok nem egységes felépítése és szerkezete. (6. ábra) 
Mi okozott gondot a Moodle használata során?

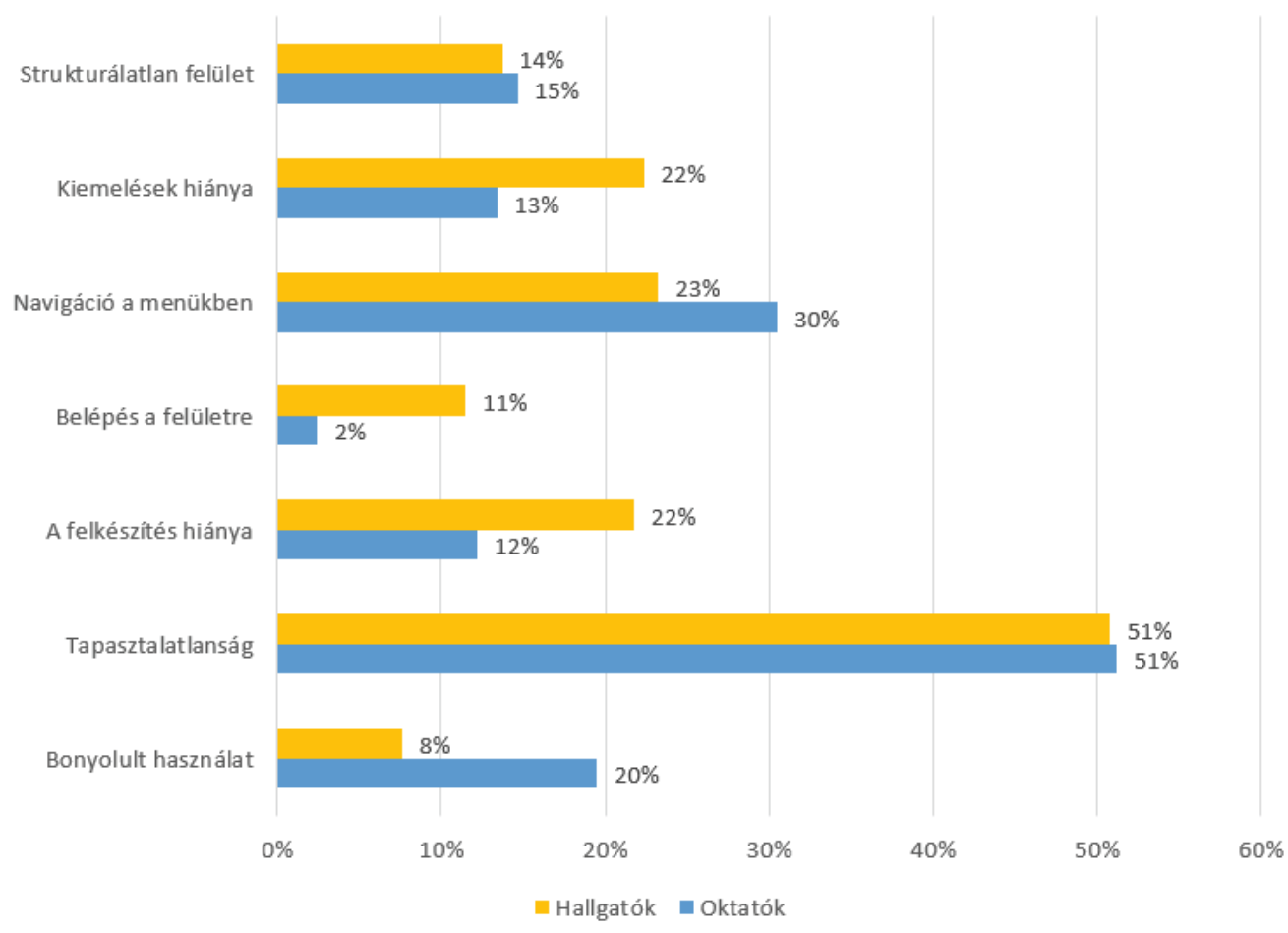

6. ábra. Az elégedettségi értékek eredményei

\section{Oktatói észrevételek a MOODLE használatával kapcsolatban}

A kérdőívek mellett online miniinterjúkat is készítettünk, amelynek kitöltése önkéntes alapon történt. Ennek célja az volt, hogy részleteiben ismerjük meg azokat a problémákat, amelyeket a kérdőív nem tudott pontosan feltárni, és a kitöltők konkretizálhassák a véleményüket. A leggyakoribbakat összegyűjtöttük, és értékeltük őket a megvalósíthatóság szempontjából.

Ezek összesítését és kivonatát ismertetjük a továbbiakban:

1. Nehezen követhetö a beadott feladatok státusza (pl. volt-e már javitva). Ez a felvetés több oktatónál is megjelent, de a megvizsgált kurzusok esetén, ha a rendszeren belül lepontozza az oktató, akkor követhetö a feladat státusza. 
2. Feladatokba történö belejavitás és visszaküldés hiánya (részben van ilyen). A javitó tanár megjegyzést tud füzni a beadott feladathoz, amit a hallgató lát, és reagálhat rá.

3. Tesztek exportja-importja nehézkes. Ez valós probléma, több lépcsöben kell paraméterezni, a kiválasztható opciók forditása nem egyértelmü.

4. Tesztek készitése bonyolult. A tesztkészitö felület valóban nehézkes a MOODLE-ban, nagy odafigyelést kiván, könnyü hibázni, és javarészt áttekinthetetlen.

5. Tesztek beállitása nehézkes, pl. pontozás. A tesztek megosztásánál a legnagyobb problémát a megfelelö személyekhez, konkrét csoportokhoz való hozzárendelés jelenti. Ez paraméterezhetö, de mindig be kell állitani.

6. Hiányzik a valós idejü kommunikáció lehetösége. A MOODLE jelenlegi verziója nem támogatja az online videókonferencia-beszélgetések lebonyolitását.

\section{Hallgatói észrevételek a MOODLE használatával kapcsolatban}

1. Lefagy a rendszer ZH közben és lassú. Ez nem a MOODLE hibája, szerver-vagy hosteredetü a probléma.

2. A tantárgyak strukturálatlanul látszódnak (pl. melyik félévhez tartozik a tárgy). Ez sajnos igaz, a tanári oldal látja, de a hallgatói nem tudja követni, melyik kurzus melyik félévben van.

3. Olyan tantárgyak is látszanak, amit a hallgató nem vett fel, vagy már teljesitett (hallgató nem törölheti). Ez elsősorban tanári hiba, de könnyen orvosolható, viszont áttekinthetöbbé lehetne tenni kevesebb paraméterrel.

4. Teszteknél mindenki kap értesitést, az is, akire nem vonatkozik. Mindkét oldalon probléma. A teszt beállitásánál megoldható.

5. Nincs a rendszeren belül valós idejü videóalapú kommunikációra lehetöség. Mindkét oldalon probléma, egyelöre nem megoldható.

6. Chatfelület átláthatatlansága (ha sokan használják egyszerre). Nem megoldható.

7. Beadási határidök jelenjenek meg kiemelve, illetve a rendszer küldjön figyelmeztetést. A hallgatók komfortérzetét pozitiv irányban jelentösen befolyásoló és szükséges változtatás.

8. Régi adatok törlése (dátumok, fórumbejegyzések, csoportok). Az elözöhöz hasonlóan fontos és megoldható kérés, de csak tanári oldalról menedzselhetö, nem automatikus és bonyolult.

9. Csoportoknak dedikált üzenetküldés lehetösége. Szintén megoldható probléma.

10. Kurzusok nem egységes szerkezete. A tanároknak ajánlott kurzussablonok készitésével megoldható. A rendszer maga az egyéni kialakitást támogatja. 


\section{Konklúziók}

A kérdőívek eredményeiből is jól látszik, hogy a hallgatói és oktatói oldalon sok a bizonytalanság a felület kezelésével kapcsolatban. Ebből fakadóan sok olyan kérés van, amely könnyen megoldható egy kis tanári és hallgatói tapasztalattal (pl. régi adatok törlése, hallgatók törlése, dátumok aktualizálása, mit lásson a tesztből a hallgató stb.). A hallgatói kérések sok esetben ezekkel egybevágnak. Bizonyos felvetések a MOODLE rendszer felépítéséből fakadóan nem megoldhatók, mint a teljesen egységes kurzusszerkezet megvalósítása vagy a chatfelület átláthatóbbá tétele, a rendezett tantárgystruktúra kialakítása és az online videókonferencia-rendszer beépítése.

Éppen ezért a megvalósításnál azokra a kihívásokra koncentráltunk, amelyek egyszerüsítik a használatot, de alapvetően nem változtatják meg a felület struktúráját.

A tapasztalatok és a kérések alapján a következő változtatások tűntek megalapozottnak és megvalósíthatónak a projekt szempontjából:

1. A kurzusok végén az oktatóknak lehetöségük van a kurzusok archiválására és alaphelyzetbe állitására, ami többlépcsős, bonyolult folyamat. Az egyik megvalósitandó programozási feladat a két müvelet egyesitése és optimalizálása a tapasztalatok felhasználásával.

2. Letölthetö tesztsablonok készitése Microsoft Word formátumban, amelyek tartalma importálható a MOODLE rendszerbe további szerkesztés nélkül.

3. Annak beépitése, hogy kötelezö legyen csoportot megadni a tesztek, illetve a feladatok kiadásánál, elsösorban olyan kurzusok esetén, ahol több csoport is ugyanahhoz az oktatóhoz tartozik egy adott félévben. Minden esetben beallitható legyen, hogy csak az kapjon értesitést, akire vonatkozik.

4. A beadási határidö elött egy meghatározható idöpontban a rendszer küldjön figyelmeztetést a határidö pontos lejártáról.

5. A hallgatói és oktatói belépések segitése érdekében a MOODLE ellenörizze az e-mail-cimeket az elsö használat elött.

\section{Közoktatás}

\section{Iskolai könyvtárak, könyvtárostanárok az iskolák mutatói?}

A digitális átállás ezen a területen sokkal nagyobb problémát okoz - mint azt bármikor gondoltuk volna -, mint a felsőoktatásban. De miért nem az iskolákkal kezdjük? Miért az iskolai könyvtárakkal? Számos szempontból az iskolai könyvtárak képviselik egy iskola minőségi mutatóinak jelentős százalékát. Ha például nem tudja egy tanár, hogy a saját 
tárgyaiból a szakirodalom vagy tanuláshoz szükséges irodalom milyen köre található a saját iskolájának könyvtárában, az baj. Még nagyobb baj, ha a tanulók figyelmét fel sem hívja az iskolai könyvtár létezésére. És ezt nemcsak az irodalom- vagy a történelemórára, hanem minden tantárgyra értjük!

Ráadásul utalva az elöző fejezetekre, az iskolai könyvtár gyakorlóhelye a tanároknak, könyvtárostanároknak, leendő gyakorló tanároknak és a tanulóknak is. Tehát a tanárképzés szorosan összefonódik az iskolákkal, könyvtárakkal. Ezzel nem mondtunk újat. Azonban a digitális átállás számos ponton kezdi megváltoztatni ezt a viszonyt. Ez lehet jó és rossz is.

Nézzük meg, hogy a hétköznapi élet tükrében hogyan vélekednek az iskolai könyvtárosok, a tanárok, könyvtárostanárok az iskolai könyvtárak helyzetéről!

A COVID-19 - a koronavírus, a pandémia és még ki tudja hány néven nevezte el a köznyelv - megjelenése óta az iskolák működésének fenntartásában, megmentésében nem nagyon esett szó a könyvtárak, konkrétan az iskolai könyvtárak szerepéről. Ugyanakkor a mindennapi könyvtár-pedagógia sok olyan kérdést vet fel, amelyek megválaszolása nem egyszerű. Kik szerepelnek a kérdéskörben? Fenntartók, intézményvezetők, könyvtárosok, könyvtárostanárok, tanárok, tanítók, diákok.

\section{Digitális hétköznapok az oktatásban és az iskolai könyvtárban 2019-2020-ban}

A jelenlegi kutatás hangsúlya elsősorban az iskolai könyvtárak szerepének, lehetőségeinek vizsgálatára helyeződött, főként a digitális oktatási szolgáltatások és a digitális könyvtár-pedagógia támogatásának vonatkozásában.

\section{Digitális könyvtár-pedagógia}

Az oktatás és az elektronikus világ kapcsolata megteremtésének gondolata már régi keletü, akár egyidős is lehet a számítógépek megjelenésével. Walter R. Fuchs már az 1960-as években foglalkozott a kérdéssel. Könyvében külön fejezetet olvashatunk „Az iskolapadot koptassuk a komputer elött" címmel az oktatógépekhez, oktatóprogramokhoz kapcsolódóan (Fuchs, 1971). Az e téren történt fejlődés dokumentálásához bőséges külföldi és hazai szakirodalom áll rendelkezésre, a fejlődési folyamatban pedig megjelennek és elterjednek - szinte hétköznapi szinten - olyan fogalmak, mint például az e-learning, blended learning stb. Egyre többet foglalkozunk a digitális létezés elméletével és gyakorlatával, ezek között pedig természetesen az oktatással is. Egyik eredménye a kutatásoknak és a fejlesztéseknek a digitális pedagógia területének kialakulása és térhódítása.

\section{A mindennapi digitális könyvtár-pedagógia legfontosabb céljai, eszközei}

A mindennapi helyett használhatnánk akár a hétköznapi jelzőt is, hiszen az előzőekben már említett szolgáltatások alkalmazása az oktatásban mára természetessé vált (legalábbis 
szeretnénk hinni, hogy egyre több intézményben gondolják így), nélkülük egyre nehezebb boldogulni az információk világában. Különösen igaz ez a tartalomszolgáltató rendszerekre, a digitális könyvtárakra és a digitális repozitóriumokra. Azonban az már kérdéses, hogy ezek használatának, az oktatásban és tanulásban történő alkalmazásának tanítása milyen mértékben kerül az iskolai könyvtáros, a könyvtárostanár feladatkörébe. (Ennek a kérdésnek a vizsgálatára a kutatás második szakaszában kerül sor.)

A másik fontos szempont, hogy mennyire alkalmas az iskolai könyvtár infrastruktúrája ennek a feladatnak az ellátására.

De mielőtt még ez kibontásra kerülne a felmérések alapján, nézzünk néhány általános, illetve alapvető szempontot a digitális könyvtárpedagógia területéhez!

Az iskolai könyvtár fogalmának elhelyezése a digitális korban nem egyszerủ feladat. Elöször is sok emberben felmerülhet a kérdés, hogy a könyvtár hagyományos funkciója mennyit veszít fontosságából a digitális világ elöre törésének következtében. A könyvek, tanulási források digitális eszközökre való letöltésének lehetősége mennyire idegeníti el a mai fiatalokat a könyvtár látogatásától?

Tény, hogy az iskolai könyvtárakat a digitális kor szerepváltásra kényszeríti, ami azonban nem jelenti azt, hogy a hagyományos funkciók teljesen háttérbe szorulnának. Másrészt pedig az iskolai könyvtár feladata jelentősen bővülhet a digitális technológia térhódításának köszönhetően. Az internet lehetővé teszi a helytől független hozzáférést, de nem teszi lehetővé a millió online információból, dokumentumok mérhetetlen mennyiségéből a releváns információ kiválogatását, valamint minimális segítséget nyújt a jó és a rossz vagy káros tartalmak szétválogatásához. Ez az a terület, ahol az iskolai könyvtárnak, a könyvtárostanárnak fontosabb szerepe van, mint bármikor volt.

A továbbiakban a teljesség igénye nélkül felsorolunk néhány tevékenységet, feladatot, amelyek a digitális könyvtár-pedagógia körébe tartoznak. Ezekről számos forrásból szerezhetünk bővebb információt (pl. e-learninges oldalak módszertani részei, a Digital Library Federation oldalai, oktatási módszertani oldalak, a MERLOT oldalai, könyvtárak oktatáshoz, képzéshez kapcsolódó oldalai stb.):

- Open Access források ismerete (digitális könyvtárak, repozitóriumok).

- Digitalizált és digitális formában eloállított dokumentumok, gyűjtemények használata, oktatásban történő felhasználásuk technikái (digitális könyvtárak, repozitóriumok).

- Információkeresési technikák elsajátítása, az információforrások értékelése.

- A digitális pedagógiai kutatás területén kialakuló új módszerek, eszközök ismerete.

- Napjainkban egyre inkább előtérbe kerül, hogy a diákok ismereteket szerezzenek az információk, dokumentumok eloállításáról. Az iskolai könyvtár egyik helyszíne lehet ennek a feladatnak (tananyag-repozitóriumok építésének segítése). 
- Digitális objektumok létrehozása pl. tananyagokhoz a tanulókkal közösen (videók, weboldalak, blogok stb.). Ezek a feladatok nem utolsósorban segíthetik a tananyagok mélyebb megértését, növelhetik a tanulók aktivitását (tananyag-repozitóriumok építésének segítése).

- Az iskolai könyvtár segíthet a létrehozott objektumok közzétételében, publikálásában (pl. Open Access formában).

- A digitális, projektalapú oktatás-tanulás jó gyakorlatainak gyüjtése.

- Szakirodalom gyüjtése a digitális pedagógiával foglalkozó oktatók számára.

- Stb.

Ezek a feladatok persze nem vagy csak részben láthatók el megfelelő infrastruktúra, felszereltség nélkül. Sajnos az iskolai könyvtárak egy részének még jelenleg is a finanszírozás jelenti a legnagyobb gondot, hiszen ahol állománygyarapításra is alig jut, ott a különböző informatikai eszközök beszerzése szinte esélytelen (bár ezen a különböző projektek, pályázatok valamelyest segítettek az utóbbi években).

Összességében azonban megállapíthatjuk tehát, hogy a digitális korszak nem veszélyezteti az iskolai könyvtárak jövőjét, sőt lehetőséget ad arra, hogy sajátos, jellegzetes könyvtári környezetet építsenek ki.

\section{A tanárok véleménye az iskolai könyvtárakról (2020)}

Marshall McLuhan szerint a korábban nyomtatott könyvhöz hozzájutó és abból tudást szerző, tipográfiai ember számára a tudás lényegében a tudás birtoklásán alapszik: különféle írásbeli forrásokból elsajátítható ismeretek összességét jelenti. Mára a fogalom helyét az elektronikus ember fogalma veszi át, „aki számára a tudást már nem az információ birtoklása, hanem az elektronikusan hozzáférhető végtelen információáradatban való eligazodás képessége határozza meg”. (McLuhan, 2011)

Az információáradatban való eligazodásra a használókat és potenciális használókat legjobban a könyvtárosok tudják felkészíteni. Ehhez azonban a könyvtáraknak rendelkeznie kell mindazzal a technológiai eszközparkkal, adatbázisokhoz való hozzáféréssel, amelyre igény jelentkezhet. Ne feledkezzünk meg arról sem, hogy a könyvtáraknak fontos társadalmi szerepe is van: a találkozás, a tanulás, az együttműködés helyszínei! A könyvtár kultúra- és értékközvetítő intézmény is, ezért fontos szerepe és felelőssége is van a digitális technológia által nyújtott lehetőségek tudatos és kritikai használatának kialakításában.

Az IFLA 2019-es trendje alapján átfogó megközelítést kell alkalmazni a fejlesztendő készségek és a tanulás módja terén: ki kell alakítani az élethosszig tartó tanulás képességét 
a könyvtárakban. A hagyományos könyvtári feladatokon túl be kell kapcsolódniuk a digitális kompetenciafejlesztésbe, és egyfajta digitális központként kell támogatást nyújtaniuk az iskolák számára. (IFLA, 2019)

Elsősorban a tanárok figyelmét szeretnénk felhívni a problémákra.

\section{A tanári felmérés eredményei}

A közoktatásban dolgozó oktatókat országos szinten kérdeztük meg, a felmérés nem reprezentatív. A válaszadási hajlandóság kétszeri kiküldés után sem felelt meg az elvártaknak. Ugyanakkor közel 1200 közoktatásban dolgozó tanár töltötte ki a kérdőívet, akik fontosnak tartották elmondani a véleménüket az iskolai könyvtárak helyzetéről.

A kérdőívek és a kereszttáblák, amelyek összevetik az adatokat az iskolai könyvtárak infrastrukturális adataival, jelenleg kiértékelés alatt vannak. Ugyanakkor a kommunikációs eszközök és a képzésmenedzsment-rendszerek használatának arányáról már kaphatunk képet.

Képzésmenedzsment-rendszerek, kommunikációs rendszerek és közösségi platformok tekintetében elmondható a viszonylag nagy számú minta alapján, hogy annál jobb, minél több. Ezen azt értjük, hogy amennyiben valaki tanulni, kutatni akar, akkor a kommunikációs rendszerek jelentősebb részét telepítse saját gépre. Ha szórakozni akar, akkor elég egy is, legfeljebb nem sikerül.

Az elsősorban kommunikációs rendszerként és az elsősorban képzésmenedzsment-rendszerként használt platformok között a megkérdezetteknek egy része nem tud konkrét különbséget megfogalmazni. A különböző rendszerek használata meglehetősen változatos, széles körben történik. A pandémiahelyzet ezt a nem mindig hasznos sokszínűséget csak fokozta. Jól érzékelhetően nem volt idő arra, hogy kikristályosodjon egy olyan életképes paletta a szabadon hozzáférhető szoftverek területén: 1. amelyek autentikusan és hatékony módon lefedik az egyes oktatási-képzési szinteket; 2. az oktatáspolitika sem tudott olyan megfelelő döntéseket hozni ennyi idő alatt, amelyek valamelyest szervezettebbé, egységesebbé tették volna a különböző platformok alkalmazását.

Ezt mutatják az alábbi diagramok adatai is. Amint már említettük, a felmérés nem reprezentatív, de minden iskolatípus képviselteti magát a megkérdezettek között. 


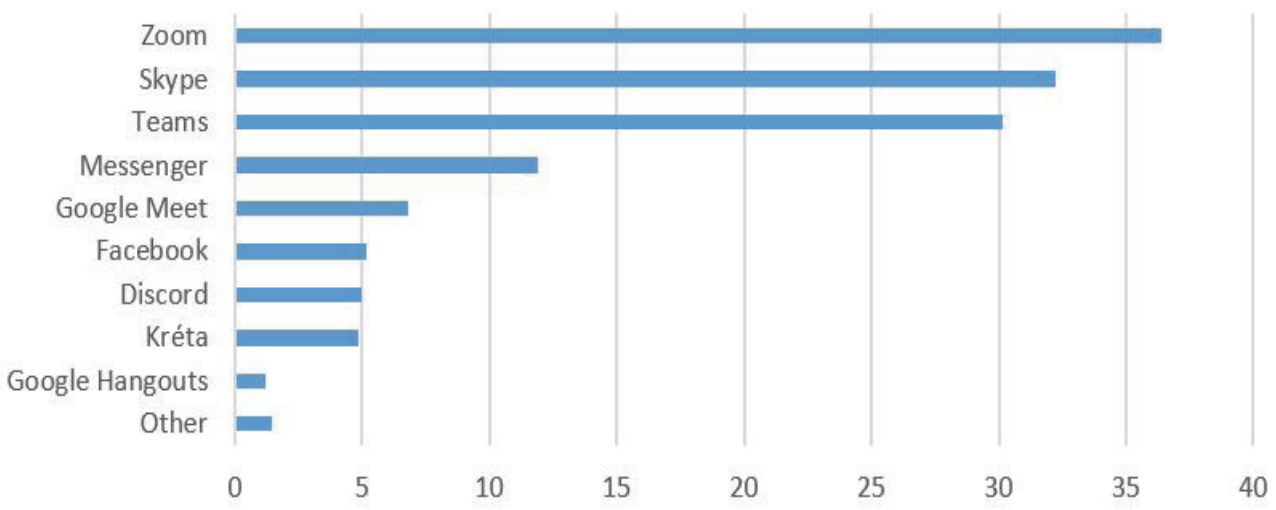

6. ábra. Melyik kommunikációs platformot használta már eddig az online oktatás során? (\%)

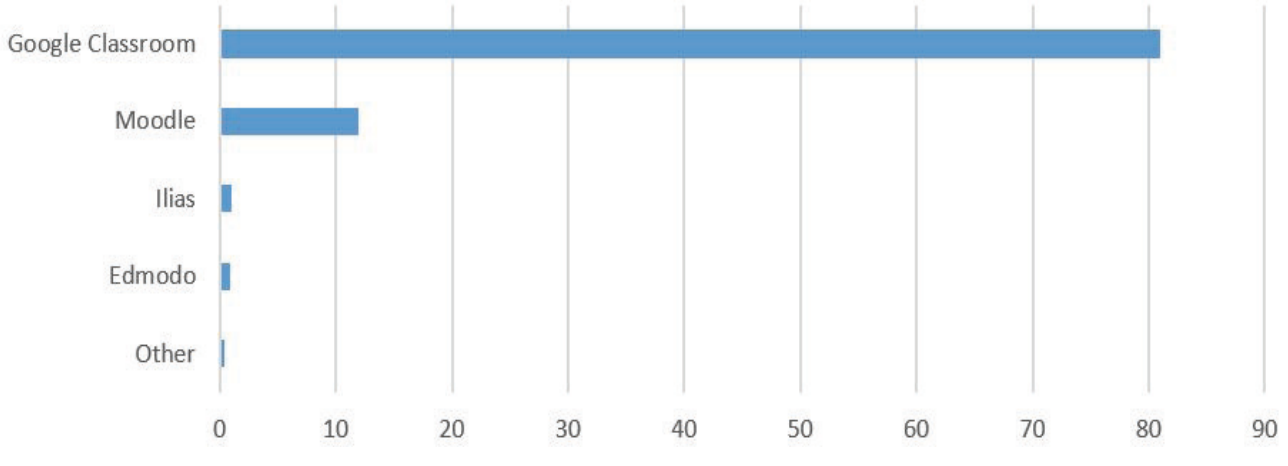

7. ábra. Melyik képzésmenedzsment-rendszert használta már eddig az online oktatás során? (\%)

\section{Az iskolai könyvtár helyzete ma}

A digitális átállás nem csupán módszertani és/vagy pénzkérdés. Az iskolai könyvtárak többségének a felszereltsége közelében sincs annak, hogy ezt az átállást meg tudja valósítani. Az iskolai könyvtár mint forrásközpont rég elveszítette jelentőségét, kivéve azokat a nagyobb iskolákat, ahol mind hely, alkalmazott, tanári kar tekintetében figyelmet fordítottak rájuk. 
A digitális átállás arról is szól, hogy ki szeretne átállni, ki szeretne segítséget kérni ehhez, ki nem szeretne egyelőre ezzel élni. A generációk fogságában vagyunk. Tisztelnünk kell azokat az akaratokat, kívánságokat, életérzéseket, amelyek nem egyeznek a miénkkel. A különböző generációk már vagy nem képesek az átállásra, vagy nem is szeretnék ezt meglépni (általában koruknál fogva). Ez nem baj.

A baj az, ha a társadalom (vagy leginkább a fenntartó) nem fogadja ezt el, vagy belehajszolja őket olyan helyzetekbe, amelyeket nem tudnak megoldani. Sajnos sok ilyen helyzettel kerülünk szembe. A felsőoktatási könyvtárak és a közkönyvtárak viszonylag jó helyzetben vannak, hiszen tudnak egyeztetni, ki tudnak állni ma a saját ügyért (többé-kevésbé). Az iskolai könyvtárak - amelyek a könyvtár-pedagógia alapintézményei - azonban többnyire magura vannak hagyva. Számos esetben nemcsak a fenntartótól, hanem az intézményvezetéstől sem kapnak támogatást, sőt a tanárok sem mindig hajlandók kiállni az iskolai könyvtár szükségessége mellett.

Természetesen ahhoz, hogy a tanárok (vagy akár a diákok) odaálljanak az ügy mellé, ahhoz elsősorban színvonalas szolgáltatás szükséges, ami visszavezet a fenntartóhoz stb. Tehát megfogtuk az ördög farkát. Valóban nincs kiút? Van. Számtalan országot, külföldi kultúrát ismerünk, ahol az iskolai könyvtár kiválóan működő intézmény, sőt a digitális átállás alapintézménye egy oktatási intézményben szinte az iskolai könyvtáron belül összpontosul (pl. Finnország, Szlovénia, USA stb.).

Valójában nem egyszerű egy „zárt” intézményen belül működő könyvtár megítélése. Mindenesetre a COVID-19, a pandémia - legalábbis a mi országunkban - a látszat szerint nem tett jót az iskolai könyvtárak működésének, hiszen ezek elsősorban fizikai (kontakt) működésre voltak felkészülve, és informatikai felszereltségük sok esetben nagyon kevés ahhoz, hogy segítsék ebben a helyzetben az iskola tanulóit és dolgozóit.

\section{Összegzés, feladatok}

Sem a felsőoktatás, sem a közoktatás, sem az iskolai könyvtárak többsége nincs és nem is volt felkészülve ezekre a fejlesztésekre: nevezetesen sem infrastruktúra, sem személyzet, sem szolgáltatás szempontjából. Ráadásul nagyon sok esetben nem élvezik a használók támogatását (diákok, tanárok) - érthetően a szolgáltatások hiányossága miatt. Éppen ezért az alábbiakban megfogalmazott gondolatok éppúgy érvényesek a közoktatásra, mint a felsöoktatásra.

Elsősorban a tanárok figyelmét szeretnénk felhívni a képzésmenedzsment-rendszerekre és az iskolai könyvtárra. Sajnos néha triviális gondolatokat kell megfogalmazni azok számára is, akik ezeket akár tudhatnák is: 
- Ezek a rendszerek nem azért müködnek esetlegesen rosszul, mert jól nem tudnak.

- A kezelőik, szakembereik nem azért nem tudnak esetenként támogatni bennünket, mert nem akarnak.

- Minden szolgáltatás a gyerekekért, a tanárokért, használókért van és a minőségi oktatásért.

\section{A menedzsment feladatai}

- Széles körủ tervezés, a technológia integrációja az egyes iskolákban.

- „Kiválósági buborékok” létrehozása, iskolák, osztályok normarendszere.

- Mi az optimális egyensúly az iskolán kívüli tanulás (online/e-tanulás) és osztályon belüli tanulás között?

- Milyen jó gyakorlatokat ismerünk ehhez? Müködnek?

- Mi szükséges ahhoz, hogy minden iskola/osztály képes legyen blended alapú tanulást-oktatást végezni webalapú eszközök használatával?

- A technológia alkalmazásának módjai (lehetőségek, rendszerkorlátozások stb.)

- Tudunk-e olyan rendszert szolgáltatásba állítani, amely lehetővé teszi a diákok számára a technológia és az eszközök felhasználásának megtanulását?

- Szélessávú használat, médiagazdag tartalom, egyetemes hozzáférhetőség (a jog és a lehetőségekhez képest) minden diák számára.

- Nyitott hozzáférés biztosítása az iskola, a fenntartó és a posztgraduális képzések között.

- Biztonságos hálózatot, biztonságos letöltés (például nyílt forráskódú szoftverek).

- Működési normák (biztonságos rendszerek előtérbe helyezése).

- Interoperábilis rendszerek alkalmazása.

- A diákok által behozott anyagok kezelése, felhasználása.

- Mindezek által a tanterv, az információs technológia fejlesztése.

- A tanárok oktatása az információs írástudás terén, online szakmai fejlesztés.

- Költséghatékonyság (pl. egyetemi gerincrendszerek használata).

- A hallgatói bemenetek felépítése.

- Technológiai döntések, stratégiai tervezés (nem csak a helyszínen, hanem a rendszer szintjén is), tekintettel a technológia integrált támogatására.

- A hallgatói szakértelem figyelembe vétele.

- Partnerségi viszonyok koordinálása.

- Stb. (részben Abram, 2009)

\section{A föszereplök feladatai: diák, tanár, könyvtáros}

A tanárok és az iskolai könyvtár kapcsolatát nem nagyon szokták vizsgálni. Csak a diákok viszonyulása érdekel mindenkit. A kettő pedig összefügg. Az a tanár, aki nem irányítja rá 
a figyelmet a könyvtárra (iskolai könyvtárra), az vélhetően maga sem használja. (Ez persze nem feltétlenül az ő hibája, hivatkozva az előzőekben leírtakra.)

- Tudja-e a tanár, hogy mire jó egy képzésmenedzsment-rendszer vagy egy iskolai könyvtár? (fizikai tér, dokumentumok, digitális tár)

- Mit várhat a tanár a képzésmenedzsment-rendszertől vagy az iskolai könyvtártól? (Ha használja, akkor ez mennyi plusz tevékenységet jelent számára?)

- Mit kap a tanár a képzésmenedzsment-rendszertől vagy az iskolai könyvtártól?

- Tudatosan használja a tanár a képzésmenedzsment rendszert és az iskolai könyvtárat vagy esetlegesen?

- Mennyire hasznos a képzésmenedzsment-rendszer vagy az iskolai könyvtár a szükséges információk beszerzésében? (pl. Kaplan, 2010)

- Mennyire hasznos a képzésmenedzsment-rendszer vagy az iskolai könyvtár az iskola elvégzéséhez?

- Mennyiben segít a képzésmenedzsment-rendszer vagy az iskolai könyvtár az IKTeszközök használatában az iskolában és otthon?

- Támogatja az iskolai könyvtár az olvasástanulást, -népszerüsítést stb?

\section{Felhasznált irodalom}

Abram, S. (2018). The future of school libraries: American Library Association (ALA): National school library: Standards for learners, school librarians and school libraries can school boards get on board? In: Internet@Schools Magazine (Letöltés: 2021. 02. 10.)

Antal P. (2020). Digitalization and Sports: ICT-related challenges in physical education teacher training. In: Abonyi-Tóth et al. (ed.): New Methods and Technologies in Education, Research and Practice. Proceedings of XXXIII. DidMatTech 2020 Conference. Budapest, ELTE Faculty of Informatics. URL: http://didmattech.inf.elte.hu/wpcontent/uploads/2020/09/Didmattech2020_Proceedings_XXXIII_v20200921.pdf (Letöltés: 2021. 02. 10.)

Crisp, E. A. - Bonk, C. J. (2018). Defining the learner feedback experience. In: TechTrends. https://doi.org/10.1007/s11528-018-0264-y

Czeglédi L. (2009). A felsőoktatás informatizálása, különös tekintettel a technikai eszközök integrációjára. In: Kis-Tóth Lajos (szerk.), Elektronikus tanulási környezetek kialakitása 1., Eger, Líceum K., 10-31. 
Davies, T. (2003). Some personal thoughts from a "traditional" academic moving towards e-learning. URL: http://elearningeuropa.info/doc.php?lng=1\&id $=1159 \&$ doclng=1 (Letöltés: 2021. 02. 10.)

Fuchs, W.R. (1971). Az új tanulási módszerek. Budapest, Közgazdasági és Jogi Kvk.

IFLA trend report (2019). URL: https://trends.ifla.org/files/trends/assets/documents/ifla_ trend_report_2019.pdf (Letöltés: 2021. 02. 10.)

Kaplan, A. G. (2010). School library impact studies and school library media programs in the United States. In: School libraries worldwide, vol. 16., no. 2.

Lengyelné, M. T. - Szűts, Z. - Racsko, R. (2020). The development of multiliteracy with Lego devices. In: Abonyi-Tóth et al. (ed.): New Methods and Technologies in Education, Research and Practice. Proceedings of XXXIII. DidMatTech 2020 Conference. Budapest, ELTE Faculty of Informatics. URL: http://didmattech.inf.elte.hu/wp-content/ uploads/2020/09/Didmattech2020_Proceedings_XXXIII_v20200921.pdf (Letöltés: 2021. 02. 10.)

McLuhan, M. (2011). The Gutenberg Galaxy. Toronto, University of Toronto Press.

Racsko, R. (2017). Digitális átállás az oktatásban. Budapest, Gondolat. https://doi.org/10.17717/IQKONYV.Racsko.2017

Skinner, B. F. (1954). The science of learning and the art of teaching. Cambridge, Mass, USA. 